\title{
Protein content and amino acid composition of commercially available plant-based protein isolates
}

\author{
Stefan H. M. Gorissen ${ }^{1}$. Julie J. R. Crombag ${ }^{1}$ - Joan M. G. Senden ${ }^{1}$ • W. A. Huub Waterval ${ }^{2}$. Jörgen Bierau ${ }^{2}$. \\ Lex B. Verdijk ${ }^{1}$. Luc J. C. van Loon ${ }^{1}$
}

Received: 19 March 2018 / Accepted: 24 August 2018 / Published online: 30 August 2018

(C) The Author(s) 2018

\begin{abstract}
The postprandial rise in essential amino acid (EAA) concentrations modulates the increase in muscle protein synthesis rates after protein ingestion. The EAA content and AA composition of the dietary protein source contribute to the differential muscle protein synthetic response to the ingestion of different proteins. Lower EAA contents and specific lack of sufficient leucine, lysine, and/or methionine may be responsible for the lower anabolic capacity of plant-based compared with animalbased proteins. We compared EAA contents and AA composition of a large selection of plant-based protein sources with animal-based proteins and human skeletal muscle protein. AA composition of oat, lupin, wheat, hemp, microalgae, soy, brown rice, pea, corn, potato, milk, whey, caseinate, casein, egg, and human skeletal muscle protein were assessed using UPLC-MS/MS. EAA contents of plant-based protein isolates such as oat (21\%), lupin (21\%), and wheat (22\%) were lower than animal-based proteins (whey $43 \%$, milk 39\%, casein 34\%, and egg 32\%) and muscle protein (38\%). AA profiles largely differed among plant-based proteins with leucine contents ranging from $5.1 \%$ for hemp to $13.5 \%$ for corn protein, compared to $9.0 \%$ for milk, $7.0 \%$ for egg, and $7.6 \%$ for muscle protein. Methionine and lysine were typically lower in plant-based proteins $(1.0 \pm 0.3$ and $3.6 \pm 0.6 \%)$ compared with animal-based proteins $(2.5 \pm 0.1$ and $7.0 \pm 0.6 \%)$ and muscle protein $(2.0$ and $7.8 \%$, respectively). In conclusion, there are large differences in EAA contents and AA composition between various plant-based protein isolates. Combinations of various plant-based protein isolates or blends of animal and plant-based proteins can provide protein characteristics that closely reflect the typical characteristics of animal-based proteins.
\end{abstract}

Keywords Essential amino acid $\cdot$ Leucine $\cdot$ Plant-based protein $\cdot$ Muscle protein synthesis $\cdot$ Protein blend

\section{Introduction}

Dietary protein intake stimulates muscle protein synthesis (Rennie et al. 1982). The muscle protein synthetic response to protein intake can vary substantially between different dietary protein types or sources. The differential muscle protein synthetic response is largely dependent on the postprandial availability of essential amino acids (and leucine in

Handling Editor: F. Blachier.

Luc J. C. van Loon

L.vanLoon@maastrichtuniversity.nl

1 NUTRIM School of Nutrition and Translational Research in Metabolism, Maastricht University Medical Centre+, PO Box 616, 6200 MD Maastricht, The Netherlands

2 Department of Clinical Genetics, Maastricht University Medical Centre+, Maastricht, The Netherlands particular) to the muscle (Atherton et al. 2010; Volpi et al. 2003). Postprandial essential amino acid availability is regulated by a number of physiological processes including dietary protein digestion, amino acid absorption, splanchnic amino acid retention, and skeletal muscle perfusion (Groen et al. 2015) as well as various dietary factors including amino acid composition, essential amino acid content, and the presence of anti-nutritional factors.

Numerous studies have assessed the postprandial muscle protein synthetic response to the ingestion of dairy (Burd et al. 2012; Gorissen et al. 2016; Pennings et al. 2011, 2012; Tang et al. 2009; Witard et al. 2014; Yang et al. 2012a) and meat (Beals et al. 2016; Burd et al. 2015; Pennings et al. 2013; Symons et al. 2007, 2009, 2011; Phillips 2012; Robinson et al. 2013). The robust postprandial increase in muscle protein synthesis rates after the ingestion of these animal-based proteins is associated with the rapid rise in plasma essential amino acid concentrations, and leucine 
in particular. In comparison, the muscle protein synthetic responses to the ingestion of plant-based proteins such as soy (Phillips 2012; Tang et al. 2009; Wilkinson et al. 2007; Yang et al. 2012b) and wheat (Gorissen et al. 2016) have been shown to be of a lesser magnitude compared with animalbased proteins. The lesser anabolic properties of plant-based proteins have been attributed to lower essential amino acid content or shortage of specific amino acids such as leucine, lysine, and/or methionine (WHO/FAO/UNU Expert Consultation 2007; van Vliet et al. 2015; Young and Pellett 1994). All amino acids are required for protein synthesis, and lack of one or more amino acids may compromise the postprandial muscle protein synthetic response. Interestingly, the anabolic properties of plant-based proteins have only been studied for a few protein sources, such as soy (Fouillet et al. 2002, 2009; Hartman et al. 2007; Phillips 2012; Tang et al. 2009; Wilkinson et al. 2007; Yang et al. 2012b; Brown et al. 2004; Volek et al. 2013), wheat (Gorissen et al. 2016; Norton et al. 2009, 2012), and rice (Joy et al. 2013), despite the great diversity in plant-based protein sources (van Vliet et al. 2015).

The use of plant-based protein isolates in food formulations has recently become of interest due to greater sustainability and lower production costs. The current market offers a wide selection of plant-based proteins, but the lack of studies comparing plant-based proteins makes it difficult to select the most optimal plant-based proteins. We previously reported substantial differences in dietary protein characteristics between various plant-based protein sources (van Vliet et al. 2015). However, this report included data from a large number of research studies that used independent analyses and assessed only a single protein source or compared a few plant-based protein sources. In the current study, we applied the same analytical procedures on a large selection of commercially available protein isolates to provide a more comprehensive overview of the dietary protein characteristics of the main plant and animal-based protein isolates that are now widely available on the market.

In the present study, we characterized various plant-based protein isolates (oat, lupin, wheat, hemp, microalgae, soy, brown rice, pea, corn, and potato), animal-based protein isolates (whey, milk, caseinate, casein, and egg), and human skeletal muscle protein. Using ultra-performance liquid chromatography tandem mass spectrometry (UPLC-MS/ MS), we assessed the amino acid composition of these protein types and sources. This study provides the basis for the identification of plant-based proteins with a high anabolic potential and for defining new plant-based protein blends that provide a complete spectrum of essential amino acids similar to most animal-based protein sources.

\section{Methods}

\section{Protein sources}

Thirty-five protein samples were selected that are presently commercially available as isolated protein powder suitable for application in human nutrition or animal feeds. Ten different plant-based protein sources including oat $(n=1)$, lupin $(n=1)$, wheat $(n=7)$, hemp $(n=1)$, microalgae $(n=1)$, soy $(n=7)$, brown rice $(n=1)$, pea $(n=3)$, corn $(n=3)$, and potato $(n=2)$ were compared with animal-based proteins including milk $(n=1)$, whey $(n=3)$, caseinate $(n=1)$, casein $(n=2)$, and egg $(n=1)$ as well as human skeletal muscle protein $(n=10)$. The plant-based protein sources selected for the current analyses account for approximately $67 \%$ of total plant-based protein intake, with oat providing $0.3 \%$, wheat providing $32.3 \%$, soy providing $2.7 \%$, brown rice providing $20.6 \%$, pea providing $1.0 \%$, corn providing $7.3 \%$, and potato providing $3.1 \%$ of total plant-based protein intake (FAOSTAT 2013). In addition, we included lupin, hemp, and microalgae in the current analyses. Lupin is a native European legume with a protein quality score similar to soy, and has become of interest as an alternative to the import of soy (Lucas et al. 2015; Mariotti et al. 2002). Microalgae have received considerable attention due to their high protein content (similar to meat, egg, soybean, and milk), presence of other beneficial nutrients, and a production that requires less water and land than other crops or animal foods (Bleakley and Hayes 2017). All protein samples were provided in kind by various suppliers: Agri Nutrition, Doetinchem, The Netherlands; Agridient, Hoofddorp, The Netherlands; Avebe, Veendam, The Netherlands; Cargill, Minnetonka, Minnesota, USA; Chamtor, Bazancourt, France; Cosucra, Warcoing, Belgium; FrieslandCampina DMV, Veghel, The Netherlands; FrieslandCampina Domo, Beilen, The Netherlands; L.I. Frank, Twello, The Netherlands; MRM Metabolic Response Modifiers, Oceanside, CA, USA; Roquette, Lestrem, France; Selecta, Goiânia-GO, Brazil; Tate and Lyle, Kimstad, Sweden; Tereos, Marckolsheim, France; Volac, Orwell, United Kingdom; Vitablend, Wolvega, The Netherlands; Wulro, Weert, The Netherlands. Protein samples were transported and stored in unopened packaging in a clean, dry, well-ventilated area at ambient temperature and humidity until further analysis. We included human skeletal muscle protein as reference protein with an 'ideal' amino acid composition when focusing on muscle protein synthesis. Human skeletal muscle samples were obtained from the $m$. vastus lateralis from ten volunteers who participated in a previously published trial (Gorissen et al. 2014). Protein samples were requested, obtained, and analyzed between December 2014 and June 2018. 


\section{Protein content analysis}

Approximately $10 \mathrm{mg}$ of protein powder (in duplicate) or freeze-dried human skeletal muscle tissue was collected in steel crucibles. The Dumas combustion method was used to determine nitrogen using the vario MAX cube CN (Elementar Analysensysteme, Germany). Protein content was calculated by multiplying the determined nitrogen content by 6.25 as the standard nitrogen-to-protein conversion factor. There is an ongoing debate on the preferred use of protein source specific nitrogen-to-protein conversion factors that are known for some but not all of the protein sources included in the current analyses (Mariotti et al. 2008). In the present study, we used a single conversion factor (6.25) to enable direct comparisons between the various protein sources.

\section{Amino acid profile analysis}

Approximately $6 \mathrm{mg}$ of protein powder or freeze-dried human skeletal muscle tissue was hydrolyzed in $3 \mathrm{~mL} 6 \mathrm{M}$ $\mathrm{HCl}$ for $12 \mathrm{~h}$ at $110{ }^{\circ} \mathrm{C}$. After hydrolysis, samples were cooled down to $4{ }^{\circ} \mathrm{C}$ to stop the hydrolyzation process. $\mathrm{HCl}$ was evaporated under nitrogen stream and the dried amino acids were reconstituted in $5 \mathrm{~mL}$ water. Amino acid standards were obtained from Sigma-Aldrich (A9906) and diluted to final concentrations of $500,375,250,125,62.5$, and $31.25 \mu \mathrm{M} .10 \mu \mathrm{L}$ of the hydrolyzed protein sample or amino acid standard solution was mixed with $1500 \mu \mathrm{L} 0.5 \mathrm{mM}$ tridecafluoroheptanoic acid (TDFHA; Sigma) in water and $10 \mu \mathrm{L}$ internal standard solution containing stable isotopelabeled amino acids (Cambridge Isotopes Laboratories) in $0.1 \mathrm{M} \mathrm{HCl}$. Amino acid concentrations were determined using ultra-performance liquid chromatography (UPLC) tandem mass spectrometry (Waterval et al. 2009). Liquid chromatography was performed at $30{ }^{\circ} \mathrm{C}$ using a Acquity UPLC BEH C18, $1.7 \mu \mathrm{m}, 2.1 \times 100 \mathrm{~mm}$ column (Waters, Milford, MA, USA) and a gradient system with the mobile phase consisting of buffer A ( $0.5 \mathrm{mM}$ TDFHA in water) and buffer B (0.5 mM TDFHA in acetonitrile) at a flow rate of $650 \mu \mathrm{L} / \mathrm{min}$ (split less). The gradient program used was: initial $99.5 \% \mathrm{~A}$ and $0.5 \% \mathrm{~B}$; linear gradient to $70 \%$ $\mathrm{A}$ and $30 \% \mathrm{~B}$ in $14 \mathrm{~min}$; hold for $3.5 \mathrm{~min}$, return to initial conditions in $1 \mathrm{~min}$ at a flow rate of $700 \mu \mathrm{L} / \mathrm{min}$, followed by equilibration for $10 \mathrm{~min}$. One minute prior to the next sample injection the flow was set to $650 \mu \mathrm{L} / \mathrm{min}$. Run-torun time was $30 \mathrm{~min}$. The injected volume was $5 \mu \mathrm{L}$. Mass spectrometry was performed using a Micromass Quattro Premier XE Tandem Mass Spectrometer (Waters, Milford, MA, USA). The mass spectrometer was used in the multiple reaction-monitoring mode (MRM) in the ESI-positive mode. The desolvation temperature was $450{ }^{\circ} \mathrm{C}$, and the source temperature was $130{ }^{\circ} \mathrm{C}$. The capillary voltage was set at $0.5 \mathrm{kV}$ and the cone voltage was set at $25 \mathrm{~V}$. Nitrogen gas was used as desolvation gas and as cone gas. Nitrogen gas was produced using an NM30L nitrogen generator (Peak Scientific, Renfrewshire, Scotland). The cone gas flow was $50 \mathrm{~L} / \mathrm{h}$ and the desolvation gas flow was $800 \mathrm{~L} / \mathrm{h}$. Optimal detection conditions were determined by constant infusion of standard solutions $(50 \mu \mathrm{M})$ in solvent A using a split system. MRM and daughter-ion scans were performed using argon as the collision gas at a pressure of $3.8 \times 10^{-3} \mathrm{mbar}$ and a flow of $0.2 \mathrm{~mL} / \mathrm{min}$.

During acid hydrolysis, the non-essential amino acids asparagine and glutamine are converted into aspartic acid and glutamic acid, respectively, and the essential amino acid tryptophan is decomposed, which precludes the ability to detect these amino acids (Fountoulakis and Lahm 1998). As tryptophan was not measured, the sum of essential amino acids includes threonine, methionine, phenylalanine, histidine, lysine, valine, isoleucine, and leucine. The acid hydrolysis was performed in the absence of oxygen and the hydrolyzation process was terminated after $12 \mathrm{~h}$ of incubation to minimize the reduction of cysteine and methionine. Although the acid hydrolysis is not optimal for all amino acids, we used this procedure for all protein samples to enable direct comparisons between the various protein sources.

\section{Results}

\section{Protein content}

Protein contents ranged between 51 and $86 \%$ of raw material (Fig. 1). Plant-based protein sources ranged between 51 and $81 \%$ and protein content was lower in hemp (51\%), lupin (61\%), oat (64\%), and corn (65\%) and higher in brown rice $(79 \%)$, pea $(80 \%)$, potato $(80 \%)$, and wheat $(81 \%)$. The

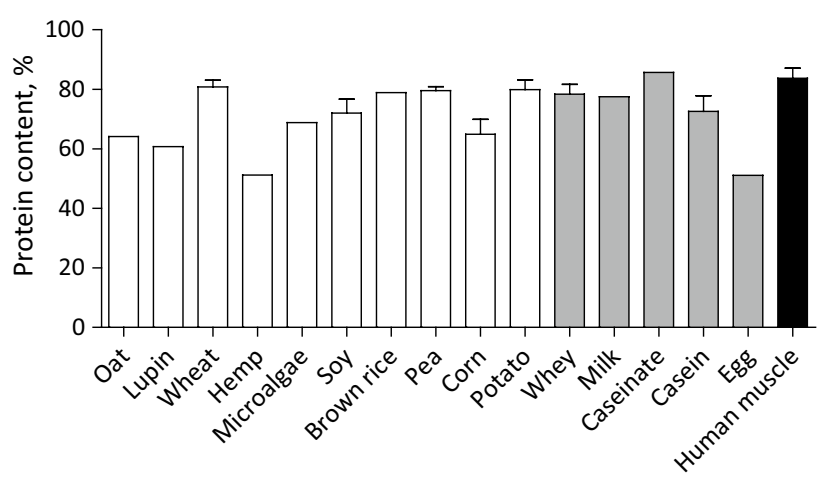

Fig. 1 Mean $( \pm$ SEM) protein content (\% of raw material) of various dietary protein sources and human skeletal muscle tissue based on the determined nitrogen content multiplied by 6.25 as the standard conversion factor. White bars represent plant-based protein sources, grey bars represent animal-derived protein sources, and black bar represents human skeletal muscle protein 
protein content of animal-based proteins ranged between $51 \%$ in egg and $86 \%$ in calcium caseinate. Freeze-dried human skeletal muscle tissue contained $84 \%$ protein. Protein contents of various samples from the same protein source differed between suppliers, with protein contents of wheat protein ranging from 74 to $88 \%$, soy protein ranging from 61 to $91 \%$, pea protein ranging from 77 to $81 \%$, corn protein ranging from 58 to $75 \%$, potato protein ranging from 77 to $83 \%$, whey protein ranging from 72 to $84 \%$, and casein ranging from 67 to $78 \%$.

\section{Essential amino acid content}

Essential amino acid contents are shown in Fig. 2. Essential amino acid contents were lower in plant-based $(26 \pm 2 \%$ of total protein) when compared with animal-based proteins $(37 \pm 2 \%$ of total protein) and human skeletal muscle protein (38\% of total protein). The essential amino acid contents of the plant-based proteins oat (21\%), lupin (21\%), wheat (22\%), hemp (23\%), and microalgae (23\%) are below the WHO/FAO/UNU amino acid requirements (WHO/FAO/ UNU Expert Consultation 2007). Thus, the essential amino acid requirement would not be met when one of these proteins would be the only protein source consumed. Note that the requirement is based on a recommended adult protein intake of $0.66 \mathrm{~g} / \mathrm{kg}$ body weight/day. Plant-based proteins that do meet the requirements for essential amino acids include soy (27\%), brown rice (28\%), pea (30\%), corn (32\%), and potato $(37 \%)$. Of the animal-based proteins, whey protein had the highest essential amino acid content of $43 \%$. Milk protein (39\%) and calcium caseinate (38\%) showed an intermediate and casein (34\%) and egg (32\%) a lower

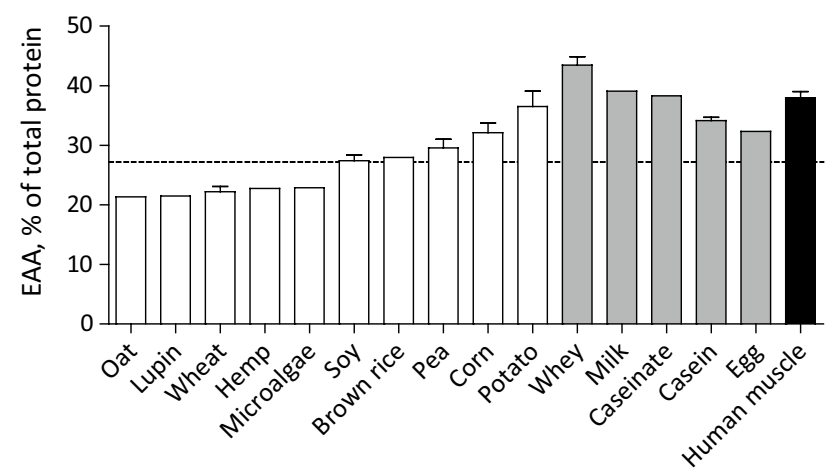

Fig. 2 Mean $( \pm$ SEM) essential amino acid (EAA) contents (\% of total protein) of various dietary protein sources and human skeletal muscle protein. White bars represent plant-based protein sources, grey bars represent animal-derived protein sources, and black bar represents human skeletal muscle protein. Dashed line represents the amino acid requirements for adults (WHO/FAO/UNU Expert Consultation 2007). Note: EAA is the sum of His, Ile, Leu, Lys, Met, Phe, Thr, and Val. Trp was not measured essential amino acid content. All animal-based proteins were well above the WHO/FAO/UNU amino acid requirements.

\section{Amino acid profiles}

Amino acid profiles differed substantially among plantbased proteins with leucine contents as low as $5.1 \%$ in hemp, $5.2 \%$ in lupin, and $5.8 \%$ in microalgae and as high as $13.5 \%$ in corn and $8.3 \%$ in potato compared to $7.6 \%$ in human skeletal muscle protein (Fig. 3a). Despite the high leucine content of corn and potato, the average leucine content of plant-based proteins was lower $(7.1 \pm 0.8 \%)$ when compared with animal-based proteins $(8.8 \pm 0.7 \%)$. Lysine and methionine contents are particularly low in plant-based proteins ( $3.6 \pm 0.6$ and $1.0 \pm 0.3 \%$, respectively) when compared with animal-based proteins $(7.0 \pm 0.6$ and $2.5 \pm 0.1 \%$,
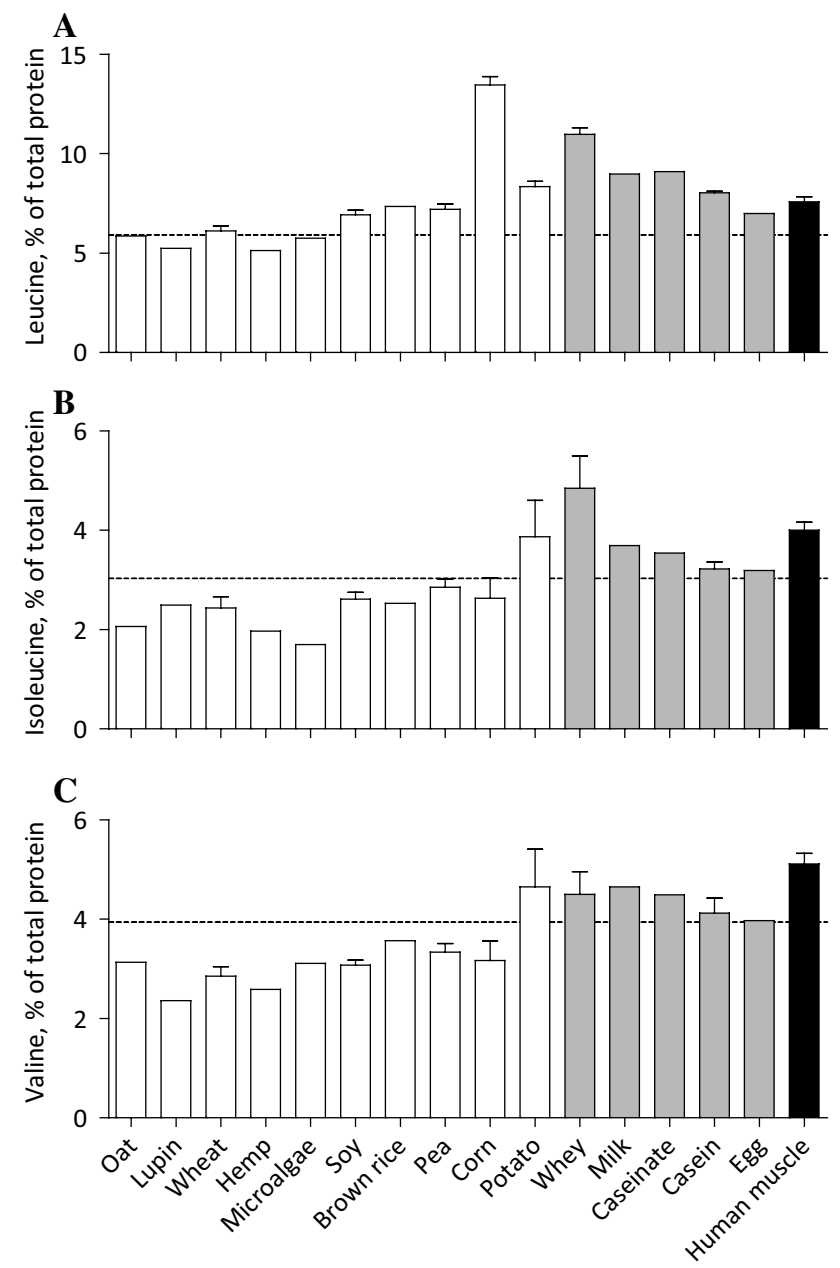

Fig. 3 Mean ( \pm SEM) leucine (a), isoleucine (b), and valine (c) contents (\% of total protein) of various dietary protein sources and human skeletal muscle protein. White bars represent plant-based protein sources, grey bars represent animal-derived protein sources, and black bar represents human muscle. Dashed line represents the amino acid requirements for adults (WHO/FAO/UNU Expert Consultation 2007) 
Fig. 4 Mean ( \pm SEM) lysine (a), methionine (b), histidine (c), phenylalanine (d), and threonine (e) contents (\% of total protein) of various dietary protein sources and human skeletal muscle protein. White bars represent plant-based protein sources, grey bars represent animal-derived protein sources, and black bar represents human muscle. Dashed line represents the amino acid requirements for adults (WHO/ FAO/UNU Expert Consultation 2007)

respectively) and human skeletal muscle protein ( 7.8 and $2.0 \%$, respectively), but with great variability between plant-based protein sources (Fig. 4a, b). The lysine content of wheat $(1.4 \%)$, corn $(1.5 \%)$, oat $(2.1 \%)$, brown rice $(2.4 \%)$, hemp $(2.8 \%)$, and lupin $(3.5 \%)$ is below the WHO/FAO/ UNU requirements and substantially lower when compared with soy $(4.6 \%)$, microalgae (5.3\%), pea (5.9\%), and potato $(6.0 \%)$. Methionine contents were low in microalgae $(0.0 \%)$, oat $(0.2 \%)$, lupin $(0.3 \%)$, pea $(0.4 \%)$, soy $(0.4 \%)$, and wheat $(0.9 \%)$, but reached the WHO/FAO/UNU requirements in potato $(1.6 \%)$, corn $(1.7 \%)$, hemp $(2.0 \%)$, and brown rice $(2.5 \%)$. Less pronounced variability was observed between plant-based and animal-based proteins in isoleucine, valine, histidine, phenylalanine, and threonine contents. Except for potato protein, the contents of the branched-chain amino acids isoleucine and valine were lower in plant-based when compared to animal-based proteins and did not reach the WHO/FAO/UNU requirements. A complete overview of the amino acid profiles as expressed in $\mathrm{g} / 100 \mathrm{~g}$ raw material is presented in Table 1.

\section{Relative protein intake}

Table 2 shows representative amounts of protein or raw material that need to be consumed to allow $2.7 \mathrm{~g}$ of leucine or $10.9 \mathrm{~g}$ essential amino acids to be ingested, which is the amount of leucine or essential amino acids present in $25 \mathrm{~g}$ whey protein that has been shown to stimulate muscle protein synthesis in humans (Gorissen et al. 2017; Mitchell et al. 2015; Witard et al. 2014; Yang et al. 2012a). Between 20 and $54 \mathrm{~g}$ of plant-based protein needs to be consumed to ingest $2.7 \mathrm{~g}$ leucine, which would be provided by, e.g., $31 \mathrm{~g}$ corn protein powder or $105 \mathrm{~g}$ hemp protein powder. This again highlights the variability among plant-based protein sources.

\section{Discussion}

This study measures and compares amino acid composition of various plant-based protein isolates including oat, lupin, wheat, hemp, microalgae, soy, brown rice, pea, corn, and potato with animal-derived proteins and human skeletal muscle protein. We observed that plant-based proteins have relatively low essential amino acid and leucine contents when compared with animal-based proteins and human
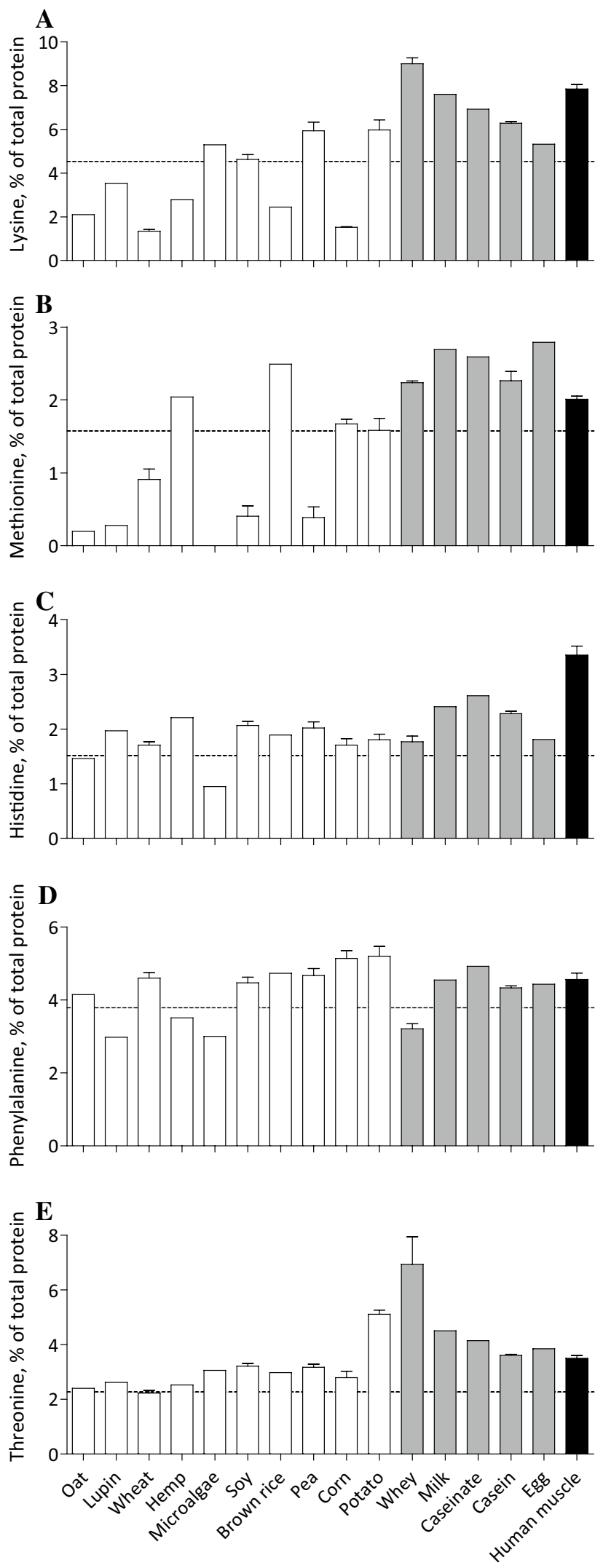


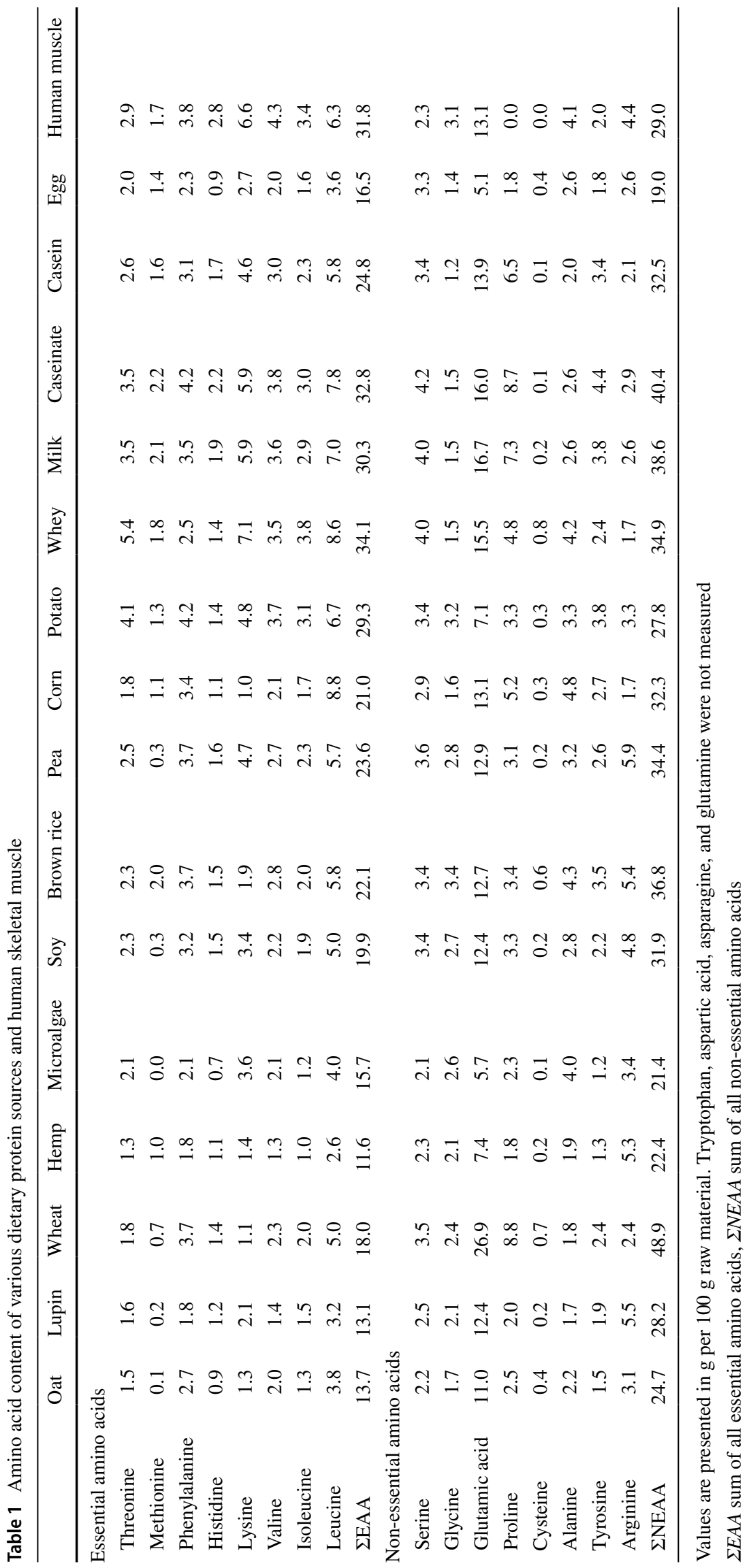


Table 2 Representative amount of protein

\begin{tabular}{llllll}
\hline & \multicolumn{2}{l}{ Matched for leucine } & & \multicolumn{2}{l}{ Matched for $\Sigma$ EAA } \\
\cline { 2 - 3 } \cline { 5 - 6 } & $\begin{array}{l}\text { Amount of } \\
\text { protein }(\mathrm{g})\end{array}$ & $\begin{array}{l}\text { Amount of } \\
\text { raw material } \\
(\mathrm{g})\end{array}$ & & $\begin{array}{l}\text { Amount of } \\
\text { protein }(\mathrm{g})\end{array}$ & $\begin{array}{l}\text { Amount of } \\
\text { raw material } \\
(\mathrm{g})\end{array}$ \\
\hline Oat & 47 & 73 & & 51 & 79 \\
Lupin & 52 & 86 & & 50 & 83 \\
Wheat & 45 & 55 & & 49 & 60 \\
Hemp & 54 & 105 & 48 & 93 \\
Microalgae & 48 & 69 & 48 & 69 \\
Soy & 40 & 55 & 40 & 55 \\
Brown rice & 37 & 47 & 39 & 49 \\
Pea & 38 & 48 & 37 & 46 \\
Corn & 20 & 31 & 34 & 52 \\
Potato & 33 & 41 & 30 & 37 \\
Whey & 25 & 32 & 25 & 32 \\
Milk & 31 & 39 & 28 & 36 \\
Caseinate & 30 & 35 & 28 & 33 \\
Casein & 34 & 47 & 32 & 44 \\
Egg & 39 & 77 & 34 & 66 \\
\hline
\end{tabular}

Amount of a certain protein source that needs to be consumed to provide $2.7 \mathrm{~g}$ leucine or $10.9 \mathrm{~g}$ essential amino acids (i.e., the same amount of leucine or essential amino acids ingested when consuming $25 \mathrm{~g}$ whey protein)

$\Sigma E A A$ sum of all essential amino acids

skeletal muscle protein. In addition, some but not all plantbased protein isolates are low in lysine and/or methionine contents. As there is a large variability in amino acid composition among the various plant-based protein sources, a balanced combination of different plant-based proteins may provide a high(er) quality protein blend.

World population growth in combination with increasingly limited resources (arable land and fresh water) has resulted in the need for alternative protein sources to meet global protein requirements. The production of plant-based foods requires less land and water and is associated with lower greenhouse gas emissions compared with animalbased foods. However, studies suggest that plant-based proteins are of lesser quality with respect to their ability to increase postprandial muscle protein synthesis rates. This belief is mainly based on the very few studies that assessed the muscle protein synthetic response to the ingestion of soy protein (Phillips 2012; Tang et al. 2009; Wilkinson et al. 2007; Yang et al. 2012b). Lower essential amino acid contents and/or relative shortage of leucine, lysine, and/or methionine in the protein may contribute to the lower anabolic capacity of plant-based proteins. However, there is a large variability in amino acid composition among different plant-based protein sources. In a recent literature review, we compared data on essential amino acid, leucine, lysine, and methionine contents between various plant and animal-based protein sources (van Vliet et al. 2015). This review used data obtained from a large selection of publications that applied many different analytical procedures to assess protein characteristics such as nitrogen content and amino acid composition. In the current study, we collected a large number of commercially available dietary protein powders and applied the same analytical procedures on all protein sources, including the Dumas combustion method to determine the protein content of the protein powder (Jung et al. 2003) and ultraperformance liquid chromatography tandem mass spectrometry to assess the amino acid composition of the protein sources (Waterval et al. 2009). Consequently, we compared protein contents as well as essential and non-essential amino acid contents and, more specifically, leucine, lysine, and methionine contents between different plant-based proteins, animal-based proteins, and human skeletal muscle protein.

Of the amino acids, the essential amino acids seem to be primarily responsible for the postprandial stimulation of muscle protein synthesis (Tipton et al. 1999a, b; Volpi et al. 2003). There is a dose-dependent relationship between the amount of essential amino acids ingested and the postprandial muscle protein synthetic response until a plateau is reached (Cuthbertson et al. 2005). When identifying dietary protein sources that could effectively be used in dietary interventions to promote muscle growth or prevent muscle loss, it is important to consider the essential amino acid content of the dietary protein source. Although we observed that the average essential amino acid contents of plant-based proteins are generally lower when compared with animalbased proteins and human skeletal muscle protein, certain plant-based proteins have a relatively high essential amino acid content. Soy, brown rice, pea, corn, and potato protein have essential amino acid contents that meet the requirements as recommended by the WHO/FAO/UNU (WHO/ FAO/UNU Expert Consultation 2007) (Fig. 2). In addition, the essential amino acid content of potato protein (37\%) is in fact greater when compared with casein (34\%) and egg (32\%). These data suggest that certain plant-based proteins could theoretically provide sufficient essential amino acids to allow a robust postprandial stimulation of muscle protein synthesis.

Upon digestion and absorption, dietary protein provides amino acids that serve as precursor for de novo muscle protein synthesis. Besides serving as precursors for de novo protein synthesis, certain amino acids can directly activate the muscle protein synthetic machinery by activating mTORC1 and downstream anabolic signaling (Atherton et al. 2010). Specifically, leucine has been shown to be sensed by Sestrin2 that promotes translocation of mTORC1 to the lysosomal membrane, where it becomes activated (Laplante and Sabatini 2012; Saxton et al. 2016; Wolfson et al. 2016), leading to activation of downstream signaling and subsequent stimulation of muscle protein synthesis. As such, the 
leucine content of the ingested protein source forms a key characteristic that modulates activation of the muscle protein synthetic machinery after protein ingestion. In this regard, we observed that hemp (5.1\% leucine) and lupin (5.2\% leucine) do not meet the WHO/FAO/UNU requirements for leucine of 5.9\% (WHO/FAO/UNU Expert Consultation 2007), whereas microalgae, oat, and wheat provide close to the leucine requirements, and soy, pea, brown rice, potato, and corn provide well above the leucine requirements (Fig. 3a). Interestingly, the leucine content of potato $(8.3 \%)$ is greater when compared with casein (8.0\%) and egg (7.0\%) and the leucine content of corn (13.5\%) is greater than whey (11.0\%) protein (compared to $7.6 \%$ in human skeletal muscle protein). It has been well established that the ingestion of $25 \mathrm{~g}$ whey protein (providing $2.7 \mathrm{~g}$ leucine) results in a robust stimulation of muscle protein synthesis rates (Gorissen et al. 2017; Mitchell et al. 2015; Witard et al. 2014; Yang et al. 2012a). Plant-based proteins could provide the same amount of leucine by adjusting the amount of protein ingested. Due to the greater leucine content of corn, 'merely' $20 \mathrm{~g}$ of protein needs to be ingested to provide $2.7 \mathrm{~g}$ leucine, while the dietary protein dose of the other plant-based proteins would need to be increased to $33 \mathrm{~g}$ (potato), $37 \mathrm{~g}$ (brown rice), $38 \mathrm{~g}$ (pea), $40 \mathrm{~g}$ (soy), $45 \mathrm{~g}$ (wheat), $47 \mathrm{~g}$ (oat), $48 \mathrm{~g}$ (microalgae), $52 \mathrm{~g}$ (lupin), and $54 \mathrm{~g}$ (hemp) (Table 2). Ingesting these amounts of protein may be sufficient to activate the muscle protein synthetic machinery, assuming that $2.7 \mathrm{~g}$ leucine is sufficient to trigger this activation. Once activated, all amino acids are required to serve as precursors for de novo tissue protein synthesis and shortage of one or more specific amino acids could compromise a sustained elevation in postprandial muscle protein synthesis rates.

The lysine and methionine contents are generally low(er) in plant-based when compared with animal-derived proteins (WHO/FAO/UNU Expert Consultation 2007; van Vliet et al. 2015; Young and Pellett 1994). The current analysis confirms these findings and shows that methionine and lysine contents are lower in plant-based proteins $(1.0 \pm 0.3$ and $3.6 \pm 0.6 \%)$ compared with animal-based proteins $(2.5 \pm 0.1$ and $7.0 \pm 0.6 \%)$ and human skeletal muscle protein (2.0 and $7.8 \%$, respectively). Interestingly, we observed a greater variability among the plant-based proteins, with some plantbased proteins providing the requirements of lysine (4.5\%) and others providing the requirements of methionine (1.6\%). More specifically, soy, microalgae, and pea contain 4.6, 5.3, and $5.9 \%$ lysine, respectively, but are low in methionine. Alternatively, corn, hemp, and brown rice contain 1.7, 2.0, and $2.5 \%$ methionine, respectively, but are low in lysine (Fig. 4a, b). Oat, lupin, and wheat protein are low in both lysine and methionine, whereas potato protein contains sufficient levels of both lysine (6.0\%) and methionine (1.6\%).

Studies investigating the anabolic properties of plantbased proteins have shown that the muscle protein synthetic response to the ingestion of soy (Tang et al. 2009; Wilkinson et al. 2007; Yang et al. 2012b) and wheat protein (Gorissen et al. 2016) is lower when compared with dairy protein. In an attempt to increase the muscle protein synthetic response to soy protein, Yang and colleagues (Yang et al. 2012b) increased the protein dose from 20 to $40 \mathrm{~g}$, but the ingestion of this higher dose of soy protein was not able to induce a greater stimulation of muscle protein synthesis. We recently showed that increasing the amount of wheat protein hydrolysate from 35 to $60 \mathrm{~g}$, thereby matching for the leucine content of $35 \mathrm{~g}$ whey protein, was able to substantially increase postprandial muscle protein synthesis rates (Gorissen et al. 2016). Although effective, simply increasing the dose of plant-based proteins to compensate for their lower anabolic properties may not always be practical or feasible. Of the ten plant-based proteins included in the current analysis, potato protein is the only protein source containing the WHO/FAO/ UNU requirements for all essential amino acids. Thus, when consuming potato protein as the only dietary protein source at the recommended adult protein intake level of $0.66 \mathrm{~g} / \mathrm{kg} /$ day, sufficient amounts of all essential amino acids should be consumed. It remains to be investigated whether the ingestion of a single meal-like amount of potato protein has the capacity to stimulate muscle protein synthesis. The other nine plant-based protein isolates included in the current analysis contain insufficient amounts of lysine and/or methionine according to the $\mathrm{WHO} / \mathrm{FAO} / \mathrm{UNU}$ requirements. The low lysine or methionine content of corn, hemp, brown rice, soy, and pea protein can be compensated for by ingesting 2-4 times more protein. Alternatively, combining corn, hemp, or brown rice (low in lysine) with soy, microalgae, or pea (low in methionine) at a 50/50 ratio results in protein blends with a more 'complete' amino acid composition. These blends contain intermediate amounts of lysine and methionine and require only 10-90\% more protein to be consumed to provide sufficient amounts of all essential amino acids (instead of the 2-4 times higher dose when a single protein source would be consumed). Oat, lupin, and wheat protein are low in both lysine and methionine, which could be compensated for by ingesting 3-8 times more protein. However, a more realistic approach would be to combine oat, lupin, or wheat protein with animal-based proteins. At a 50/50 ratio, these blends require only $5-40 \%$ more protein to be consumed to provide sufficient amounts of all essential amino acids. Certainly, many more protein blends combining two or more protein sources at various ratios could be created. Creating protein blends seems to offer benefits over increasing the dose of protein consumed, as protein blends can provide sufficient amounts of all essential amino acids at a lower protein dose. Whether the ingestion of a single mealsize bolus of these protein blends increases muscle protein synthesis rates remains to be assessed. Promising results have been obtained in both young (Reidy et al. 2013, 2014, 
2016) and older individuals (Borack et al. 2016) when using a protein blend composed of $50 \%$ caseinate, $25 \%$ whey protein, and $25 \%$ soy protein. Future studies should assess the anabolic properties of protein blends with a greater relative amount of plant-based proteins, protein blends composed of solely plant-based proteins designed to provide a more balanced essential amino acid profile, and/or individual plantbased proteins with a more optimal amino acid composition. Dietary intervention can then implement plant-based proteins or protein blends with greater anabolic properties as a more sustainable protein source to meet global protein requirements and support overall growth, health, as well as muscle mass maintenance throughout the lifespan.

In conclusion, there are large differences in amino acid content and amino acid composition between the various plant-based protein sources. Combinations of various plantbased protein sources or blends of animal- and plant-based proteins may provide protein characteristics that closely reflect the typical characteristics of animal-based protein sources.

Acknowledgements We gratefully acknowledge Wendy Sluijsmans, Hasibe Aydeniz, and Janneau van Kranenburg for their technical assistance.

Author contributions The authors' contributions to the manuscript were as follows: SHMG, LBV, and LJCvL designed the research; SHMG, JJRC, JMGS, WAHW, and JB conducted the research; and SHMG and LJCvL wrote the paper. All authors have read and approved the final manuscript.

Funding Supported by Top Institute Food and Nutrition, which is a public-private partnership on precompetitive research in food and nutrition.

\section{Compliance with ethical standards}

Conflict of interest SHMG, JJRC, JMGS, WAHW, and JB reported no conflicts of interest. LJCvL and LBV have received speaking honoraria or consulting fees from Friesland Campina and Nutricia Research. The industrial partners have contributed to the project through regular discussions.

Ethical approval All procedures performed in studies involving human participants were in accordance with the ethical standards of the institutional and/or national research committee and with the 1964 Helsinki declaration and its later amendments or comparable ethical standards. This article does not contain any studies with animals performed by any of the authors.

Open Access This article is distributed under the terms of the Creative Commons Attribution 4.0 International License (http://creativeco mmons.org/licenses/by/4.0/), which permits unrestricted use, distribution, and reproduction in any medium, provided you give appropriate credit to the original author(s) and the source, provide a link to the Creative Commons license, and indicate if changes were made.

\section{References}

Atherton PJ, Smith K, Etheridge T, Rankin D, Rennie MJ (2010) Distinct anabolic signalling responses to amino acids in $\mathrm{C} 2 \mathrm{C} 12$ skeletal muscle cells. Amino Acids 38(5):1533-1539. https://doi. org/10.1007/s00726-009-0377-x

Beals JW, Sukiennik RA, Nallabelli J, Emmons RS, van Vliet S, Young JR, Ulanov AV, Li Z, Paluska SA, De Lisio M, Burd NA (2016) Anabolic sensitivity of postprandial muscle protein synthesis to the ingestion of a protein-dense food is reduced in overweight and obese young adults. Am J Clin Nutr 104(4):1014-1022. https:// doi.org/10.3945/ajcn.116.130385

Bleakley S, Hayes M (2017) Algal proteins: extraction, application, and challenges concerning production. Foods 6(5):33. https://doi. org/10.3390/foods6050033

Borack MS, Reidy PT, Husaini SH, Markofski MM, Deer RR, Richison AB, Lambert BS, Cope MB, Mukherjea R, Jennings K, Volpi E, Rasmussen BB (2016) Soy-dairy protein blend or whey protein isolate ingestion induces similar postexercise muscle mechanistic target of rapamycin complex 1 signaling and protein synthesis responses in older men. J Nutr 146(12):2468-2475. https://doi. org/10.3945/jn.116.231159

Brown EC, DiSilvestro RA, Babaknia A, Devor ST (2004) Soy versus whey protein bars: effects on exercise training impact on lean body mass and antioxidant status. Nutr J 3:22. https://doi. org/10.1186/1475-2891-3-22

Burd NA, Yang Y, Moore DR, Tang JE, Tarnopolsky MA, Phillips SM (2012) Greater stimulation of myofibrillar protein synthesis with ingestion of whey protein isolate v. micellar casein at rest and after resistance exercise in elderly men. Br J Nutr 108(6):958-962. https://doi.org/10.1017/s0007114511006271

Burd NA, Gorissen SH, van Vliet S, Snijders T, van Loon LJ (2015) Differences in postprandial protein handling after beef compared with milk ingestion during postexercise recovery: a randomized controlled trial. Am J Clin Nutr 102(4):828-836. https://doi. org/10.3945/ajen.114.103184

Cuthbertson D, Smith K, Babraj J, Leese G, Waddell T, Atherton P, Wackerhage H, Taylor PM, Rennie MJ (2005) Anabolic signaling deficits underlie amino acid resistance of wasting, aging muscle. FASEB J 19(3):422-424. https://doi.org/10.1096/fj.04-2640fje

Food Balance Sheets (2013) Food and Agriculture Organization of the United Nations Statistics Division. http://www.fao.org/faost at/en/\#data/FBS

Fouillet H, Mariotti F, Gaudichon C, Bos C, Tome D (2002) Peripheral and splanchnic metabolism of dietary nitrogen are differently affected by the protein source in humans as assessed by compartmental modeling. J Nutr 132(1):125-133

Fouillet H, Juillet B, Gaudichon C, Mariotti F, Tome D, Bos C (2009) Absorption kinetics are a key factor regulating postprandial protein metabolism in response to qualitative and quantitative variations in protein intake. Am J Physiol Regul Integr Comp Physiol 297(6):R1691-R1705. https://doi.org/10.1152/ajpregu.00281 .2009

Fountoulakis M, Lahm HW (1998) Hydrolysis and amino acid composition of proteins. J Chromatogr A 826(2):109-134

Gorissen SH, Burd NA, Hamer HM, Gijsen AP, Groen BB, van Loon LJ (2014) Carbohydrate coingestion delays dietary protein digestion and absorption but does not modulate postprandial muscle protein accretion. J Clin Endocrinol Metab 99(6):2250-2258. https://doi.org/10.1210/jc.2013-3970

Gorissen SH, Horstman AM, Franssen R, Crombag JJ, Langer H, Bierau J, Respondek F, van Loon LJ (2016) Ingestion of wheat protein increases in vivo muscle protein synthesis rates in healthy older men in a randomized trial. J Nutr. https://doi.org/10.3945/ jn. 116.231340 
Gorissen SH, Horstman AM, Franssen R, Kouw IW, Wall BT, Burd NA, de Groot LC, van Loon LJ (2017) Habituation to low or high protein intake does not modulate basal or postprandial muscle protein synthesis rates: a randomized trial. Am J Clin Nutr 105(2):332-342. https://doi.org/10.3945/ajcn.115.129924

Groen BB, Horstman AM, Hamer HM, de Haan M, van Kranenburg J, Bierau J, Poeze M, Wodzig WK, Rasmussen BB, van Loon LJ (2015) Post-prandial protein handling: you are what you just ate. PLoS One 10(11):e0141582. https://doi.org/10.1371/journ al.pone. 0141582

Hartman JW, Tang JE, Wilkinson SB, Tarnopolsky MA, Lawrence RL, Fullerton AV, Phillips SM (2007) Consumption of fat-free fluid milk after resistance exercise promotes greater lean mass accretion than does consumption of soy or carbohydrate in young, novice, male weightlifters. Am J Clin Nutr 86(2):373-381

Joy JM, Lowery RP, Wilson JM, Purpura M, De Souza EO, Wilson SM, Kalman DS, Dudeck JE, Jager R (2013) The effects of 8 weeks of whey or rice protein supplementation on body composition and exercise performance. Nutr J 12:86. https://doi. org/10.1186/1475-2891-12-86

Jung S, Rickert DA, Deak NA, Aldin ED, Recknor J, Johnson LA, Murphy PA (2003) Comparison of Kjeldahl and Dumas methods for determining protein contents of soybean products. J Am Oil Chem Soc 80(12):1169. https://doi.org/10.1007/s11746-003-0837-3

Laplante M, Sabatini DM (2012) mTOR signaling in growth control and disease. Cell 149(2):274-293. https://doi.org/10.1016/j. cell.2012.03.017

Lucas MM, Stoddard FL, Annicchiarico P, Frias J, Martinez-Villaluenga C, Sussmann D, Duranti M, Seger A, Zander PM, Pueyo JJ (2015) The future of lupin as a protein crop in Europe. Front Plant Sci 6:705. https://doi.org/10.3389/fpls.2015.00705

Mariotti F, Pueyo ME, Tome D, Mahe S (2002) The bioavailability and postprandial utilisation of sweet lupin (Lupinus albus)-flour protein is similar to that of purified soyabean protein in human subjects: a study using intrinsically $15 \mathrm{~N}$-labelled proteins. Br J Nutr 87(4):315-323. https://doi.org/10.1079/bjnbjn2002526

Mariotti F, Tome D, Mirand PP (2008) Converting nitrogen into protein-beyond 6.25 and Jones' factors. Crit Rev Food Sci Nutr 48(2):177-184. https://doi.org/10.1080/10408390701279749

Mitchell CJ, McGregor RA, D'Souza RF, Thorstensen EB, Markworth JF, Fanning AC, Poppitt SD, Cameron-Smith D (2015) Consumption of milk protein or whey protein results in a similar increase in muscle protein synthesis in middle aged men. Nutrients 7(10):8685-8699. https://doi.org/10.3390/nu7105420

Norton LE, Layman DK, Bunpo P, Anthony TG, Brana DV, Garlick PJ (2009) The leucine content of a complete meal directs peak activation but not duration of skeletal muscle protein synthesis and mammalian target of rapamycin signaling in rats. J Nutr 139(6):1103-1109. https://doi.org/10.3945/jn.108.103853

Norton LE, Wilson GJ, Layman DK, Moulton CJ, Garlick PJ (2012) Leucine content of dietary proteins is a determinant of postprandial skeletal muscle protein synthesis in adult rats. Nutr Metab (Lond) 9(1):67. https://doi.org/10.1186/1743-7075-9-67

Pennings B, Boirie Y, Senden JM, Gijsen AP, Kuipers H, van Loon LJ (2011) Whey protein stimulates postprandial muscle protein accretion more effectively than do casein and casein hydrolysate in older men. Am J Clin Nutr 93(5):997-1005. https://doi. org/10.3945/ajen.110.008102

Pennings B, Groen B, de Lange A, Gijsen AP, Zorenc AH, Senden JM, van Loon LJ (2012) Amino acid absorption and subsequent muscle protein accretion following graded intakes of whey protein in elderly men. Am J Physiol Endocrinol Metab 302(8):E992-E999. https://doi.org/10.1152/ajpendo.00517.2011

Pennings B, Groen BB, van Dijk JW, de Lange A, Kiskini A, Kuklinski M, Senden JM, van Loon LJ (2013) Minced beef is more rapidly digested and absorbed than beef steak, resulting in greater postprandial protein retention in older men. Am J Clin Nutr 98(1):121-128. https://doi.org/10.3945/ajen.112.051201

Phillips SM (2012) Nutrient-rich meat proteins in offsetting age-related muscle loss. Meat Sci 92(3):174-178. https://doi.org/10.1016/j. meatsci.2012.04.027

Reidy PT, Walker DK, Dickinson JM, Gundermann DM, Drummond MJ, Timmerman KL, Fry CS, Borack MS, Cope MB, Mukherjea R, Jennings K, Volpi E, Rasmussen BB (2013) Protein blend ingestion following resistance exercise promotes human muscle protein synthesis. J Nutr 143(4):410-416. https://doi. org/10.3945/jn.112.168021

Reidy PT, Walker DK, Dickinson JM, Gundermann DM, Drummond MJ, Timmerman KL, Cope MB, Mukherjea R, Jennings K, Volpi E, Rasmussen BB (2014) Soy-dairy protein blend and whey protein ingestion after resistance exercise increases amino acid transport and transporter expression in human skeletal muscle. J Appl Physiol 116(11):1353-1364. https://doi. org/10.1152/japplphysiol.01093.2013

Reidy PT, Borack MS, Markofski MM, Dickinson JM, Deer RR, Husaini SH, Walker DK, Igbinigie S, Robertson SM, Cope MB, Mukherjea R, Hall-Porter JM, Jennings K, Volpi E, Rasmussen BB (2016) Protein supplementation has minimal effects on muscle adaptations during resistance exercise training in young men: a double-blind randomized clinical trial. J Nutr 146(9):1660-1669. https://doi.org/10.3945/jn.116.231803

Rennie MJ, Edwards RH, Halliday D, Matthews DE, Wolman SL, Millward DJ (1982) Muscle protein synthesis measured by stable isotope techniques in man: the effects of feeding and fasting. Clin Sci (Lond) 63(6):519-523

Robinson MJ, Burd NA, Breen L, Rerecich T, Yang Y, Hector AJ, Baker SK, Phillips SM (2013) Dose-dependent responses of myofibrillar protein synthesis with beef ingestion are enhanced with resistance exercise in middle-aged men. Appl Physiol Nutr Metab 38(2):120-125. https://doi.org/10.1139/apnm-2012-0092

Saxton RA, Knockenhauer KE, Wolfson RL, Chantranupong L, Pacold ME, Wang T, Schwartz TU, Sabatini DM (2016) Structural basis for leucine sensing by the Sestrin2-mTORC1 pathway. Science 351(6268):53-58. https://doi.org/10.1126/scien ce. $\operatorname{aad} 2087$

Symons TB, Schutzler SE, Cocke TL, Chinkes DL, Wolfe RR, PaddonJones D (2007) Aging does not impair the anabolic response to a protein-rich meal. Am J Clin Nutr 86(2):451-456

Symons TB, Sheffield-Moore M, Wolfe RR, Paddon-Jones D (2009) A moderate serving of high-quality protein maximally stimulates skeletal muscle protein synthesis in young and elderly subjects. J Am Diet Assoc 109(9):1582-1586. https://doi.org/10.1016/j. jada.2009.06.369

Symons TB, Sheffield-Moore M, Mamerow MM, Wolfe RR, PaddonJones D (2011) The anabolic response to resistance exercise and a protein-rich meal is not diminished by age. J Nutr Health Aging 15(5):376-381

Tang JE, Moore DR, Kujbida GW, Tarnopolsky MA, Phillips SM (2009) Ingestion of whey hydrolysate, casein, or soy protein isolate: effects on mixed muscle protein synthesis at rest and following resistance exercise in young men. J Appl Physiol 107(3):987992. https://doi.org/10.1152/japplphysiol.00076.2009

Tipton KD, Ferrando AA, Phillips SM, Doyle D Jr, Wolfe RR (1999a) Postexercise net protein synthesis in human muscle from orally administered amino acids. Am J Physiol 276(4 Pt 1):E628-E634

Tipton KD, Gurkin BE, Matin S, Wolfe RR (1999b) Nonessential amino acids are not necessary to stimulate net muscle protein synthesis in healthy volunteers. J Nutr Biochem 10(2):89-95

van Vliet S, Burd NA, van Loon LJ (2015) The skeletal muscle anabolic response to plant- versus animal-based protein consumption. J Nutr 145(9):1981-1991. https://doi.org/10.3945/jn.114.204305 
Volek JS, Volk BM, Gomez AL, Kunces LJ, Kupchak BR, Freidenreich DJ, Aristizabal JC, Saenz C, Dunn-Lewis C, Ballard KD, Quann EE, Kawiecki DL, Flanagan SD, Comstock BA, Fragala MS, Earp JE, Fernandez ML, Bruno RS, Ptolemy AS, Kellogg MD, Maresh CM, Kraemer WJ (2013) Whey protein supplementation during resistance training augments lean body mass. J Am Coll Nutr 32(2):122-135. https://doi.org/10.1080/07315724.2013.793580

Volpi E, Kobayashi H, Sheffield-Moore M, Mittendorfer B, Wolfe RR (2003) Essential amino acids are primarily responsible for the amino acid stimulation of muscle protein anabolism in healthy elderly adults. Am J Clin Nutr 78(2):250-258

Waterval WA, Scheijen JL, Ortmans-Ploemen MM, Habets-van der Poel CD, Bierau J (2009) Quantitative UPLC-MS/MS analysis of underivatised amino acids in body fluids is a reliable tool for the diagnosis and follow-up of patients with inborn errors of metabolism. Clin Chim Acta 407(1-2):36-42. https://doi.org/10.1016/j. cca.2009.06.023

WHO/FAO/UNU Expert Consultation (2007) Protein and amino acid requirements in human nutrition. World Health Organ Tech Rep Ser 935:1-265

Wilkinson SB, Tarnopolsky MA, Macdonald MJ, Macdonald JR, Armstrong D, Phillips SM (2007) Consumption of fluid skim milk promotes greater muscle protein accretion after resistance exercise than does consumption of an isonitrogenous and isoenergetic soyprotein beverage. Am J Clin Nutr 85(4):1031-1040
Witard OC, Jackman SR, Breen L, Smith K, Selby A, Tipton KD (2014) Myofibrillar muscle protein synthesis rates subsequent to a meal in response to increasing doses of whey protein at rest and after resistance exercise. Am J Clin Nutr 99(1):86-95. https://doi. org/10.3945/ajcn.112.055517

Wolfson RL, Chantranupong L, Saxton RA, Shen K, Scaria SM, Cantor JR, Sabatini DM (2016) Sestrin2 is a leucine sensor for the mTORC1 pathway. Science 351(6268):43-48. https://doi. org/10.1126/science.aab2674

Yang Y, Breen L, Burd NA, Hector AJ, Churchward-Venne TA, Josse AR, Tarnopolsky MA, Phillips SM (2012a) Resistance exercise enhances myofibrillar protein synthesis with graded intakes of whey protein in older men. Br J Nutr 108(10):1780-1788. https ://doi.org/10.1017/s0007114511007422

Yang Y, Churchward-Venne TA, Burd NA, Breen L, Tarnopolsky MA, Phillips SM (2012b) Myofibrillar protein synthesis following ingestion of soy protein isolate at rest and after resistance exercise in elderly men. Nutr Metab (Lond) 9(1):57. https://doi. org/10.1186/1743-7075-9-57

Young VR, Pellett PL (1994) Plant proteins in relation to human protein and amino acid nutrition. Am J Clin Nutr 59(5 Suppl):1203S-1212S 